\title{
EFFECTS OF UTILIZATION DEVELOPMENTS AND TRENDS ON THE FOREST ${ }^{1}$
}

\author{
By D. W. GRAY ${ }^{2}$
}

As a member of this panel, my first thought or question to myself was, "What does the title mean? What are the developments and trends in utilization the author had in mind?"

It seemed to me that the more significant developments might be summarized under two headings:

1. Mechanization of production operations;

2. Utilization of an increasing number of species.

That these developments and trends have brought about changes which have had and which will have a continuing effect on the forest seems selfevident, although there is room for a wide variety of opinions as to the directions in which the effects will be felt and whether or not they are beneficial. It is my opinion that our forests have benefited and I see no reason why this should not continue to be so.

It is sometimes the case that a change or an improvement designed to accomplish some particular end or to serve a special purpose turns out to be of itself more important than the purpose or end which it was to implement. I suggest that it is in this light that we should look at our subject for today.

The common denominator to progress in the management of our forests, in all its phases, is accessibility-in other words roads. Without roads the utilization developments we are considering could not have been implemented. Some may take the view that it is the mechanization of our production operations that has led to the construction of roads. I think it sounder to hold the view that it is the development of roads which has made it possible to apply our new methods and procedures. I think it is not a case of a debate as to which comes first-like the hen or the egg. Roads are the sine qua non to progress in forest management. Roads come first.

I suggest then that it is worth our while and pertinent to today's discussion to study briefly the effect on the forest of the development of roads:

1. With the advent of roads a reasonable degree of forest protection becomes a practical target. All of you, I am certain, know of instances where substantial forest areas have been decimated by fire or other damaging agencies and where suppression was impractical because of the inaccessibility of the location: no roads, no really effective protection.

2. The accessibility which roads provide means that crop losses due to decadence or overmaturity can be materially decreased. The tree or the stand can be harvested when it is ripe and in its prime. The effective yield of our forests is increased. Similarly, where areas have been damaged by fire or insects or fungi, salvage operations are possible if the area is

\footnotetext{
${ }^{1}$ A paper presented at the 48th Annual Meeting of the Canadian Institute of Forestry, held at Chicoutimi, Quebec, October 2 - 5, 1956.

${ }^{2}$ K.V.P. Company, Espanola, Ontario.
} 
accessible. Again, the losses and wastages are reduced.

3. Not only will our direct losses be reduced and salvage possibilities improved where losses are experienced, but the construction of roads into formerly inaccessible forest areas means that those areas are no longer inaccessible. Roads increase the area of economically available forest land. And they have a double-barrelled action in this respect. Not only are additional forest areas made accessible, but areas which have been economically unavailable for reasons other than purely physical ones of access, are made economically available by reason of the road development. With the steadily increasing population of our country and the rapidly mounting demands for forest products, an effective increase in accessible forest area and economically available timber supplies is most important to all of us. Even without any intensification in silvicultural practices the effective yield of our forests is increased-our forests are made more valuable to the owners-the citizens of Canada - by the development of forest roads.

4. With the ready access and economy of operation which roads afford, it will become possible to practice more intensive management on an extensive scale. Our net increment can be increased by the practice of such cultural activities as thinning of young stands, maintenance of full stocking throughout our forest lands, and the selective operation of areas or stands for maximum production. All of you are aware of the wide spread between actual average yields or increment obtained from unmanaged forests and the potential of managed stands. With the development of roads we can anticipate being able to practice intensive management and of enjoying the benefits therefrom.

5. Roads make it possible to mechanize the harvesting of our forest crops. In many instances this means we can operate both summer and winter; it means the establishment in our cutover lands of conditions much more favorable to natural regeneration; and when viewed in the light of our improved fire protection potential, a much better chance of bringing the new stand through to merchantability. The mechanization that follows roads is the direct means of increasing the economically available acres. Species, which were not harvested formerly, become available; the yield per acre is increased; costs are reduced; and we practice better silviculture -because we have roads.

6. The integrated use of our forest lands becomes realistic once roads are established. The forests may serve their full purpose of providing not only a source of wood fibre, but areas for recreation for fish and wildlife management, for watershed protection and stream flow control. These uses are not incompatible, but they cannot be fully developed until we have full accessibility.

7. And finally one more point, and a most important one, in this admittedly very incomplete listing of the effect on our forests of the development of roads: Full forest management will become a reality only when all of our woods workers-our harvesters-are trained to be practicing silviculturalists in their day-to-day work in the woods. This condition will come about only when we have a stable labor force resident in the forest 
areas. And in turn this will materialize only when it is possible to have forest communities where men and their families can live a normal life in the woods. Once again this means roads.

\section{SuMmary}

You may wonder why I have chosen to belabor the question of forest roads, and to this audience.

All of us should be conscious of the inadequacy of our present forest road system, but even in such a group as this the point is not always fully realized or appreciated. Certainly there are instances where small areas are well developed, but from whatever province you hail, I think you would agree that your present forest roads fall far short of the requirements of a sound forest management system.

Why is this the case? In part, at least, it is because the general public does not fully understand the importance of our forests to our national welfare. And second, because there is a much more complete lack of knowledge or understanding of the essentiality of roads to the well being of our forests.

This is a most important and vital question, and we as professional men and as members of the Institute are being derelict in our duty if we do not take advantage of any and every opportunity to dissipate this barrier of lack of understanding of and complacency with our present position. If we are to lead the development of forest management, we must have full public support for our programmes. This will come about only when there is full and complete public understanding of the soundness of such programmes and of the fact that roads are an essential. 